\title{
PROTECT,IA MEDICALĂ, ELEMENT CHEIE ÎN ASIGURAREA CONTINUITĂȚII ACTIVITĂŢILOR CENTRELOR MILITARE, SUB PRESIUNEA CONSTANTĂ DE CONTAMINARE CU VIRUSUL SARS-CoV-2
}

\author{
MEDICAL PROTECTION, A KEY ELEMENT IN ENSURING \\ THE CONTINUITY OF THE MILITARY CENTERS ACTIVITIES, \\ UNDER THE CONSTANT PRESSURE OF CONTAMINATION \\ WITH THE SARS-COV-2 VIRUS
}

Lt.col.drd. Ionel COTOARBĂ*

\begin{abstract}
În condițiile unei pandemii, priorităţile pentru orice comandant trebuie să fie axate pe protecția personalului propriu, pe menținerea capacității de luptă și pe îndeplinirea misiunilor. Aplicarea măsurilor de protecție a personalului se realizează într-o concepție unitară și gradual, în funcție de evoluția pandemică din zona de responsabilitate. Apariția unor virusuri din ce în ce mai contagioase și favorizarea răspândirii rapide a acestora la nivel global prin diversitatea și complexitatea transporturilor terestre, aeriene și navale ne obligă să reconsiderăm poziția în următoarele aspecte: instruirea și recrutarea personalului; realizarea stocurilor; adaptarea măsurilor de protecție, în special a personalului; optimizarea procedurilor de operare, pe baza unor principii clar definite.
\end{abstract}

In the event of a pandemic, the priorities for any commander must be focused on protecting their own personnel, maintaining combat capability and carrying out the missions. The personnel protection measures are implemented in a unitary and gradual conception depending on the pandemic evolution in the area of responsibility. The appearance of increasingly contagious viruses and the promotion of their rapid spread globally through the diversity and complexity of land, air and naval transport, forces us to reconsider our position on the following issues: training and recruitment of staff; making stocks; adaptation of protection measures, in particular of personnel; optimization of operating procedures based on clearly defined principles.

Cuvinte-cheie: centre militare; planificare; protecția personalului; măsuri de protecție; circuite; zone de risc.

Keywords: military centers; planning; personnel protection; protection measures; circuits; risk areas.

Odată cu declararea de către Organizația Mondială a Sănătății, în martie 2020, a pandemiei de COVID-19, ca urmare a răspândirii fulminante a infectărilor provocate de virusul SARS-CoV-2 și instituirii stării de urgență pe întreg teritoriul României, începând cu 16 martie 2020를 fiecare instituţie din sistemul național de securitate, ordine publică și siguranță națională/SNAOPSN a trecut prin momente dificile, înțelegând mai mult sau mai puțin necesitatea implementării măsurilor minime, impuse de autorităţile guvernamentale și locale.

\footnotetext{
* Centrul Militar Județean Argeș

e-mail: ionelcotoarba@yahoo.com
}

La nivelul unităților militare, asupra problematicii în discuție s-a simțit, pe bună dreptate, necesitatea coordonării structurilor prin ordine, instrucțiuni, reglementări, mesaje realiste de prezentare a situației la nivel global, regional, național și local.

În opinia noastră, fiecare comandant/manager a aplicat măsurile recomandate într-o interpretare proprie, în lipsa unor proceduri coerente de acțiune. Tocmai din acest motiv, dar și ca urmare a reușitei noastre, cel puțin până la această dată ${ }^{2}$, de a comunica zero cazuri de infectare cu noul virus, ne propunem să prezentăm acțiunile, activităţile și măsurile întreprinse la nivelul Centrului Militar Județean Argeș, spre analiză și, totodată, ca un ghid de conduită în astfel de situații. 
Mulți susțin că am avut noroc, alții spun că suntem prea exagerați, însă noi spunem că, pe lângă un dram de șansă, reuşita noastră s-a bazat pe respectarea unor principii: anticipare; adaptabilitate; flexibilitate în aplicarea unor măsuri; gradualitate; economie de forțe și mijloace; concentrarea efortului; mobilitatea restrictivă (stabilirea priorităţilor) ${ }^{3}$.

Tocmai din specificul centrelor militare de a interacționa permanent cu rezerviștii, cu potențialii candidați pe timpul procesului de recrutare, din nenumăratele acțiuni de promovare directă a instituţiei în şcoli, unități militare, prin standuri organizate în cadrul unor evenimente locale, din interacțiunea cu veteranii de război prin vizitele întreprinse prin programul ,acasă la veterani”", din colaborarea permanentă cu secțiile de poliție, cu autorităţile administrației publice locale, cu operatorii economiciși cu structurile din SNAOPSN din zona de responsabilitate a derivat aducerea în prim-plan a problematicii.

\section{Stabilirea zonelor de risc și a circuitelor}

Încă de la început, trebuie să menționez că, înainte de pandemie, în activitățile curente se relaționa cu publicul prin accesul în săli de așteptare. Atribuirea riscului s-a făcut plecând de la ipoteza că personalul propriu și cel din afara instituției primesc o protecție corespunzătoare.

Concepția noastră pentru stabilirea zonelor de risc a avut la bază delimitarea fizică a unor zone, în funcție de ameninţare, de potențialele pericole și vulnerabilități.

Zona roșie reprezintă spațiul vizibil delimitat și marcat corespunzător, unde se produce interacțiunea iniţială cu o persoană din exterior. În acest perimetru, se face triajul: interogarea minoră cu privire la problema în cauză, completarea chestionarului COVID-19, se realizează termometrizarea și instructajul privind accesul spre ghișeu sau biroul de informare-recrutare. Această zonă este catalogată ca zonă de risc mare, poate fi un birou în care s-a identificat o persoană contaminată și care, anterior contaminării, a fost zonă verde sau galbenă.

Zona galbenă este conturată pe baza spațiilor în care se relaționează cu publicul. Accesul în aceste spații se realizează cu respectarea cumulativă a unor condiții: triajul realizat, măsurile de protecție în exercițiu (portul măștii, decontaminarea mâinilor/ portul mănușilor chirurgicale, decontaminarea încălțămintei, respectarea circuitului și a distanţării sociale). Zilnic, aceste zone se aerisesc și se decontaminează cu soluții și UV, conform specificațiilor produsului.

Zona verde însumează toate celelalte spații cărora nu li s-a atribuit culoarea galbenă sau verde. De regulă, în această zonă își desfășoară activitatea personalul propriu. Personalul poartă mască, zilnic se decontaminează suprafețele, inclusiv echipamentele de comunicații. La apariţia unor suspiciuni, a unor situații justificate, se face decontaminare cu UV, dar acest tip de acțiune este focusată pe zona galbenă.

Totodată, la nivelul structurii, am stabilit trei circuite fără intersectare, axate strict pe protecția personalului propriu și pe cel cu care am interacționat ulterior, cu mențiunea că portul măștii a fost instituit încă de la început, prin anticiparea evoluției la nivel național.

Traseele stabilite în cadrul primului circuit sunt adresate personalului propriu, care, la începerea programului, după parcarea autovehiculelor în incinta unității, este termometrizat și interogat la triajul epidemiologic, efectuat de persoana desemnată. Ulterior, își decontaminează mâinile şi încălțămintea, iar după ce semnează în registrul special destinat despre absența IACRS ${ }^{5}$ sau a altor simptome care se încadrează în definiţia de caz a bolii (febră, tuse, disfagie, cefalee, rinoree etc.), se permite accesul la program. În cazul manifestării/ apariţiei simptomelor, persoana în cauză este extrasă imediat și trimisă spre investigare, cu respectarea procedurilor stabilite la nivel naţional.

Persoana respectivă are obligația de a informa imediat la aflarea deciziei medicale și să prezinte o adeverință din care rezultă că nu prezintă risc de contaminare cu virusul SARS-CoV-2, concediul medical sau alte documente din care rezultă starea de sănătate, pentru întreprinderea unor măsuri adecvate de oprire a răspândirii infestării.

Pentru relaţionarea cu publicul pe probleme de evidență militară, am stabilit cel de-al doilea circuit. În acest sens, spaţiul special destinat este amenajat să asigure distanțarea socială prin marcarea limitelor de siguranță, iar pentru o comunicare adecvată cu petentul, a fost montat un panou transparent de protecție.

Fiecare petent care se prezintă la sediul centrului militar, după termometrizare este 
preluat și îndrumat să completeze un chestionar de evaluare COVID-19, stabilit prin procedura operațională proprie. Înainte de intrarea în sala de așteptare, fiecare persoană este invitată să-și efectueze decontaminarea cu soluții a mâinilor și încălțămintei. Ulterior, acesta va aștepta în zona special marcată pentru asigurarea distanţării sociale, până când va fi preluat de personalul de serviciu la ghișeu. Personalul de serviciu și cel administrativ a fost instruit ca, după relaţionarea cu fiecare persoană, să execute dezinfectarea suprafețelor de lucru.

Al treilea circuit și set de măsuri vizează candidații și personalul din cadrul biroului informare-recrutare. Prezentarea candidaților la sediul centrului militar, pentru orientarea acestora sau pentru finalizarea dosarului de candidat, se realizează, prioritar, printr-o programare în vederea asigurării distanțării sociale în sălile de lucru și respectării restricțiilor stabilite la nivel național.

Candidații sunt îndrumați permanent pentru a respecta itinerarele prestabilite şi marcate corespunzător. Înainte de intrarea în sala biroului informare-recrutare, candidatul și însoțitorul acestuia își decontaminează încălțămintea și mâinile cu soluție pe bază de alcool sau prin spălare cu apă și săpun timp de 20-40 de secunde. După încheierea activităţii cu fiecare candidat, personalul recrutor execută dezinfectarea suprafețelor de lucru cu materiale și soluții puse la dispoziție de către personal din cadrul structurii administrative.

Spaţiile destinate serviciului la ghişeu și biroului au fost catalogate ca zone galbene, având la bază două aspecte principale publicul și dorința de a realiza o separare clară a circuitelor.

In acord cu programul de lucru aprobat, zilnic se execută decontaminarea cu UV a spaţiilor destinate executării serviciului la ghișeu și a celor de relaționare cu candidații.

\section{Protecția personalului}

În realizarea eficientizării acțiunilor de protecție a personalului propriu, am avut permanent în vedere instruirea periodică, asigurarea echipamentelor și materialelor de protecție, completarea stocurilor, adaptarea și îmbunătățirea măsurilor de protecție ordonate.

Prin instruirea periodică, credem că am reușit formarea unei conduite demne de luat în seamă, bazată permanent pe dialog, încredere reciprocă, informații credibile și expuneri fundamentate. Prelucrările cu privire la respectarea măsurilor de protecție, distanțare socială, portul măștii de protecție, spălatul pe mâini, dezinfectarea suprafețelor de lucru, aerisirea spațiilor, cele cu privire la riscul transmiterii virusului SARS-CoV-2 chiar și de la persoane asimptomatice s-au realizat și prin aplicarea de materiale informative, explicite, plasate la punctul de triaj epidemiologic, la ghișeul de relații cu publicul, în grupurile sanitare și pe fiecare palier.

Totodată, prin prezența medicului și a psihologului la care suntem arondați, am reușit să menținem moralul personalului la un nivel ridicat, aspect verificat și prin testele specifice, aplicate chiar în partea de mari frământări și de identificare a unor soluții de rezolvare a unei contaminări comunitare la nivel naţional. Dialogul cu angajaţii despre măsurile adoptate, presiunea constantă de contaminare pot conduce la identificarea persoanelor care au nevoie de sprijin psihosocial.

De asemenea, o pondere considerabilă în reușita noastră este în mare măsură atribuită implementării ordinelor primite de la eșaloanele superioare, care au perceput permanent rezolvarea problemei ca pe un efort comun. Stabilirea programului de lucru pe ture sau decalarea acestuia, dar și libertatea comandanților de a-și adapta măsurile au contribuit la evitarea epuizării personalului.

Spre exemplificare, la atingerea unor sarcini unde a fost necesar un efort susţinut, am încercat, pe cât posibil, să evităm comasarea personalului la sediul institutiei, prin trimiterea unor echipe pe mai multe direcții în aria de responsabilitate, reușind îndeplinirea obiectivelor planificate. Astfel de acțiuni au avut dublu scop, pe de o parte, reducerea posibilelor tensiunilor intrapersonale inerente, generate de stresul că poți fi contaminat de cel cu care relaționezi zilnic, iar pe de altă parte, îmbunătățirea mentală prin extracția din mediul birocratic apăsător, completată de un risc asumat, de conștientizarea că poți fi mai puțin expus în acest mod.

Rezultatele măsurilor întreprinse au fost evidențiate în starea de sănătate a personalului, fapt ce a favorizat executarea concediilor de odihnă în totalitate, dar după o regulă derivată din dialog și analize, prin care persoana în cauză avea o perioadă de recreere în jur de o săptămână, urmând ca 14 zile să le petreacă în zona de domiciliu/zonă sigură, 
timp în care putea să-și dea seama despre o posibilă contaminare.

Ieșirea din stereotipuri poate a fost elementul cel mai important în succesul nostru de a evita infectarea cu noul virus, reușind să relaționăm direct cu peste 160 de operatori economici, executând acțiuni de promovare a profesiei militare în toate instituțiile de învățământ din județ (206 școli gimnaziale și licee), relaţionând cu aproximativ 2.000 de candidați, cu peste 700 de petenţi și să ne cinstim veteranii de război așa cum știm noi mai bine, prin programul ,acasă la veterani”, alături de reprezentanți din cadrul Direcției Calității Vieții Personalului și de asociațiile reprezentative din județ.

Reușita în completare cu resurse umane și materiale a unor structuri militare a fost rodul acțiunilor sinergice ale personalului propriu, al structurii completate și nu în ultimul rând al personalului din structurile de poliție.

Bineînțeles că aceste reușite sunt fundamentate pe relațiile de colaborare remarcabile interinstituționale cu autoritățile publice locale și cu structurile din SNAOPSN, consolidate pe parcursul celor peste 50 de ani de experiență.

Totuşi, trebuie precizat și faptul că, în funcție de incidenţa cazurilor la nivel local, unele activități au fost suspendate sau replanificate, când situația a fost favorabilă, iar altele, precum analize, convocări, inclusiv cele de pregătire a aleșilor locali și operatorilor economici, s-au desfășurat prin corespondență sau online ${ }^{6}$.

Continuitatea activităţii centrului militar a fost susţinută de verificările și controalele interne și cele ale eșaloanelor superioare, prin care s-a realizat o radiografie completă, s-au conturat sarcini și noi măsuri de protecție.

\section{Măsuri specifice de protecție}

Pentru fiecare manager, a întreprinde și a aplica toate măsurile de prevenire și protecție împotriva contaminării cu virusul SARS-CoV-2 nu trebuie să fie doar o responsabilitate, ci și o obligație morală de a minimiza riscurile profesionale. Infectarea angajaților poate avea impact negativ asupra îndeplinirii sarcinilor, activităților curente și, implicit, asupra realizării obiectivelor ${ }^{7}$.

Concluziile desprinse din comportamentul, caracteristicile și rezistența virusurilor la condițiile de mediu, perioada de incubație, patogenitatea, contagiozitatea și rata letalităţii contribuie la adoptarea unor măsuri asumate ${ }^{8}$.

Astfel, toate măsurile de protecție aplicate au vizat, în special, sănătatea personalului și, în particular, câștigarea de timp până la descoperirea unui vaccin.

Printre primele măsuri adoptate de la declararea pandemiei au fost, pe lângă cele legate de reducerea numărului de persoane în birouri, cele axate pe informare și instruire, realizate, inițial, în exterior, ulterior, şi pe platforma electronică de instruire COVID-19, unde au fost postate ordinele primite/ transmise și numeroasele materiale de informare. Aici, apreciem, în mod special, suportul constant al Direcției de Informare și Relații cu Publicul din cadrul Ministerului Apărării Naționale, care a reușit permanent să ne ofere o imagine cuprinzătoare și realistă privind evoluția contaminărilor și a unor ordine, date, statistici și informări de interes, astfel cunoscând permanent ponderea ameninţărilor și riscurilor din zona de dispunere.

Montarea dozatoarelor de igienizare în zone uşor accesibile pentru personalul propriu şi vizitatori, promovarea unor materiale de informare privind spălarea mâinilor și dezinfectarea în mod regulat a suprafețelor de lucru, a spațiilor comune sunt considerate măsuri elementare, care au condus la conștientizarea pericolului în rândul angajaților, aspect important în gestionarea situației.

Cele mai stringente probleme au fost cele legate de asigurarea necesarului de echipamente de protecție individuală, biocide, echipamente și materiale specifice. Aceste nevoi au fost prioritizate și rezolvate, într-un timp relativ redus, cu sprijinul autorităţilor locale, unităţii militare care ne asigură din punct de vedere logistic și al eșaloanelor superioare. Din acest punct, nu a mai fost decât un pas în a stabili circuite și măsuri de dezinfecție și decontaminare cu soluții sau raze UV.

Circuitele realizate respectă câteva reguli: decontaminare zilnică, înainte de începerea programului și ori de câte ori există o suspiciune, inclusiv cu raze UV; accesul controlat, realizat prin termometrizare, portul echipamentelor de protecție (cel puțin mască), completare chestionar COVID-19, decontaminare mâini și încălțăminte; trasee marcate și materiale informative pentru ghidare, avertizare și conștientizarea pericolului; realizarea zonelor de lucru cu risc redus de infectare prin reducerea personalului, montarea panourilor de 
protecție, aerisire și decontaminare zilnică, portul măștii de protecție.

Asigurarea distanțării sociale prin trasarea marcajelor, inclusiv în sălile de așteptare și în baza sportivă pentru desfășurarea ședințelor practic-aplicative, adunărilor sau inspecțiilor a fost a măsură eficientă și prin prisma faptului că s-au decongestionat aglomerările de personal în spații închise. Această măsură a fost completată cu montarea panourilor transparente de protecție în birouri, la ghișeu și în sala destinată informăriirecrutării. Fiecărui recrutor i s-a stabilit un punct de lucru personalizat, echipamente de protecție individuală (măști chirurgicale, mănuși, viziere), materiale și soluții pentru dezinfectarea suprafețelor de lucru, după fiecare interacțiune cu candidatul.

Luând în considerare că decontaminarea RBC se planifică și se execută în scopul menținerii/ restabilirii capacității de luptă, reducând contaminarea la un risc neglijabil, astfel încât să fie asigurată continuitatea activităților și îndeplinirea misiunilor ${ }^{9}$, dezinfectarea spațiilor exterioare, cu accent pe zona roșie, s-a efectuat, în prima parte a pandemiei, cu sprijinul unității care ne asigură din punct de vedere logistic, ulterior, după dotarea cu echipamente specifice de către personalul care încadrează structura administrativă, printr-o instruire, în prealabil, a acestuia și a întregului personal care încadrează propria structură.

Activitățile executate în zona de responsabilitate au fost desfășurate cu respectarea măsurilor de prevenire a contaminării cu virusul SARS-CoV-2, pe baza unei planificări minuțioase (stabilire algoritm, check list, telefoane, mesaje de clarificare a situației, recunoașteri etc.). Câteva reguli, aparent elementare, au contribuit la succesul nostru de a raporta zero contaminați COVID-19, prin reducerea timpuluide expunere/interacțiunecufiecare operator economic, secție de poliție, veteran, de regulă sub 15 minute, de a înlocui echipamentele de protecție și de a executa o minimă decontaminare a mâinilor. Autovehiculele au fost echipate cu prosoape de hârtie, cu pungi pentru deșeuri și cu produse necesare dezinfectării mâinilor și suprafețelor cu care se intră frecvent în contact.

Decalarea programului, programul secvențial (14 zile de lucru, 14 zile de recuperare), asigurarea spațiilor de lucru cu echipamente și materiale, reducerea aglomerărilor și prin misiuni executate simultan pe mai multe direcții, comasarea perioadelor de desfășurare a concediilor de odihnă au contribuit la asigurarea unei protecții optime a personalului propriu.

Prin măsuri de protecție adaptate specificului structurii, am reușit să câștigăm timpul necesar până la realizarea vaccinului. Ținând cont că întregul personal dorește să fie vaccinat și la nivelul Uniunii Europene, sunt aprobate trei tipuri de vaccin, credem că războiul dus împotriva unui inamic nevăzut va fi încheiat odată cu dobândirea imunizării, ca urmare a aplicării rapelului.

Efectele generate de pandemia de COVID-19 și perspectiva evoluției ciclice a virusului ne obligă, pe de o parte, la vigilență și prudență, iar pe de altă parte, să continuăm și să dezvoltăm noi măsuri de protecție pentru a ,crește capacitatea de gestionare a unei asemenea crize", în special în ceea ce privește creșterea rezilienței structurilor ${ }^{10}$.

\section{Concluzii}

Toate acțiunile și măsurile de protecție aplicate trebuie fundamentate științific, pe baza unor analize pertinente și a unui proces de planificare riguros, care include o evaluare continuă a riscurilor, amenințărilor și pericolelor din proximitatea zonei de dispunere, pentru identificarea celor mai bune soluții în vederea evitării, limitării și eliminării cazurilor de contaminare, în situația pandemică generată de virusul SARS-CoV-2.

Pe scurt, la apariția unei situații de tipul pandemiei de COVID-19, gestionarea stresului; evaluarea continuă a riscurilor, amenințărilor, pericolelor și vulnerabilităților; identificarea, adaptarea și aplicarea graduală a măsurilor de protecție pot fi un algoritm de succes.

Informațiile prezentate ne dorim să constituie repere pentru conducătorii instituțiilor militare și nu numai, în gestionarea unei situații de tipul celei abordate, în menținerea funcționalității structurii, în proiectarea și desfășurarea activităților specifice.

Într-o lume a dezvoltării covârşitoare a tehnologiei informației, stabilirea unor niveluri de protecție recunoscute cel puțin la nivel național, realizarea unor baze de date interinstituționale care pot fi interogate cu privire la persoanele infectate, completate de suportul specialiștilor pentru ,înţelegerea modului de transmitere a agentului patogen, a gradului de virulență și letalitatea contaminării la nivel local, regional ori global"11, sunt aspecte care pot contribui la asigurarea unei protecții adecvate. 


\section{Buletinul Universităţii Naţionale de Apărare „Carol I”}

\section{NOTE:}

1 Decretul semnat de președintele României, domnul Klaus Werner Iohannis, privind instituirea stării de urgență pe teritoriul României, din 16 martie 2020.

24 martie 2021, data transmiterii articolului spre verificare și publicare în Buletinul Universităţii Naţionale de Apărare „Carol I” nr. 2/2021.

3 *** Manualul protecției CBRN, București, 2015, p. 18.

4 Program inițiat și demarat de Direcția calității vieții personalului, din cadrul MApN.

5 Infecția acută a căilor respiratorii superioare.

6 *** HG nr. 969, din 22 august 2007, privind organizarea, desfăşurarea şi conducerea pregătirii pentru apărare a persoanelor cu atribuţii de conducere în domeniul administrației publice, la nivel central și local, Art. nr. 1.

$7 \mathrm{https} / / / \mathrm{www}$.ilo.org/wcmsp5/groups/public, accesat la 22.02.2021.

8 Ion Mitulețu, ,Suntem pregătiți pentru a gestiona o criză biologică?", Revista de chimie militară nr. 18/2020, p. 9.

9 Ion Mitulețu, Alexandru Herciu, Apărarea CBRN in operația brigăzii mecanizate, Editura Universității Naționale de Apărare, București, 2014, p. 88.

10 [Administrația prezidențială], Strategia națională de apărare a țării pentru perioada 2020-2024, București, 2020, p. 8.

11 Ion Mitulețu, „Suntem pregătiți pentru a gestiona o criză biologică?", Revista de chimie militară nr. 18/2020, p. 9.

\section{BIBLIOGRAFIE}

*** Legea nr. 446/2006 privind pregătirea populației pentru apărare.

*** Hotărârea Guvernului României nr. 969, din 22 august 2007, privind organizarea, desfășurarea şi conducerea pregătirii pentru apărare a persoanelor cu atribuții de conducere în domeniul administrației publice, la nivel central şi local.

*** Manualul protecției CBRN, București, 2015.

[Administrația prezidențială], Strategia națională de apărare a țării pentru perioada 2020-2024, București, 2020.

Mitulețu Ion, „Suntem pregătiţi pentru a gestiona o criză biologică?", Revista de chimie militară nr. 18/2020.

Mitulețu Ion, Herciu Alexandru, Apărarea CBRN în operația brigăzii mecanizate, Editura Universităţii Naţionale de Apărare, București, 2014. https://www.ilo.org/wcmsp5/groups/public 